\title{
Is service fairness influencing customers' satisfaction and intention to pay insurance premium? A case in BPJS Kesehatan Indonesia
}

\author{
Diena Dwidienawati \\ Mts Arief \\ Sri Bramantoro Abdinagoro \\ Bina Nusantara University (BINUS), Indonesia
}

\author{
Keywords \\ BPJS Kesehatan, Intention to pay, Satisfaction, Service Fairness, BPJS Kesehatan
}

\begin{abstract}
This study discusses the importance of service fairness variables - Interactional Fairness, Procedural Fairness, and Distributive Fairness - toward customer satisfaction, which further leads to customer intention to pay. There is limited previous empirical research on the effect of service fairness to service delivery, particularly in the healthcare industry. The authors hypothesised that there was a positive influence from three variables of service fairness, from customer satisfaction, to customer satisfaction, to intention to pay. Using the descriptive quantitative method, this pilot study was conducted to review the service delivery of BPJS Kesehatan service providers in various cities in Indonesia, with BPJS Kesehatan members as respondents. Data analysis was analysed with PLS-SEM with SmartPLS software. The study showed that there was a positive impact of Interactional Fairness and Distributive Fairness on customer satisfaction, and customer satisfaction on intention to pay. However, this study failed to show the relationship between Procedural Fairness to customer satisfaction. This study strengthens the building evidence of service fairness to customer satisfaction, specifically in-service delivery and in healthcare industry.
\end{abstract}

Corresponding author: Diena Dwidienawati

Email addresses for corresponding author: diena.tjiptadi@gmail.com

First submission received: $20^{\text {th }}$ December 2017

Revised submission received: $14^{\text {th }}$ February 2018

Accepted: 25 $5^{\text {th }}$ March 2018

\section{Introduction}

Studies have found that besides quality evaluation, fairness is another important factor which influences satisfaction (Oliver, 2015). Oliver and Swan (1988), in Vinagre \& Neves (2010), confirm that as disconfirmation of expectation, fairness is considered as an important predictor of satisfaction. It is assumed that patients are satisfied when they perceive treatment is fair.

Previous studies review fairness in various industries, including retail banking (Chebat \& Slusarczyk, 2005), air travel, restaurants, auto repair, dental (Goodwin \& Ross, 1992), hotels, and the retail-wholesaler relationship (Brown et. al., 2006). However, the issues covered by fairness studies are mostly service recovery (Goudarzi, Borges, \& Charles, 2013; Mattila, Cho, \& Cheyenne, 2011a; Mccollkennedy, Sparks, \& Nguyen, 2011; Noone, 2012; Prasongsukarn, Patterson, \& Patterson, 2012; Ro \& Olson, 2014; Sharifi \& Aghazadeh, 2016; Yilmaz, Varnali, \& Tari, 2016c), organisational behaviour (Beugre \& Baron, 2001; Chan \& Lai, 2017; J. B. DeConinck, 2010b; W. M. Hur, Park, \& Moon, 2014; Karkoulian, Assaker, \& Hallak, 2016) and price fairness (Fernandes \& Calamote, 2016; Homburg, Totzek, \& Krämer, 2014; Malc, Mumel, \& Pisnik, 2016). There are still a few studies reviewing fairness in service delivery and its impact on satisfaction. Furthermore, the author only found two studies done in the healthcare industry (Ramsaran-Fowdar, 2008; Vinagre \& Neves, 2010).

Most fairness studies are conducted with an experimental design (Goudarzi et al., 2013; Homburg et al., 2014; Malc et al., 2016; Ro \& Olson, 2014; Sharifi \& Aghazadeh, 2016). The experimental design might give high internal validity, but there is a trade off with external validity (Sekaran \& Bougie, 2016). Only a few studies, especially in service delivery, are conducted with a survey design.

Besides commitment, trust, positive emotion, and attitude are known to be the antecedents of behaviour intention (Abubakar, Ilkan, Meshall Al-Tal, \& Eluwole, 2017; Fernet, Trépanier, Demers, \& 
Austin, 2017; Gan \& Li, 2018; Hussein, Oon, \& Fikry, 2017; Liang, Choi, \& Joppe, 2018), customer satisfaction is one of the most studied antecedents of behaviour intention. Customer experience is considered a critical influence on proceeding behaviour in product purchase (Joo, Park, \& Shin, 2017).

Indonesia is one of the low and middle-income countries aiming to improve their health financing system and to implement universal health coverage (UHC). Starting just in January 2014, and within less than three years, BPJS Kesehatan has successfully had a large coverage. In January 2017, BPJS Kesehatan has 172.97 million members, according to BPJS official website. It is considered the biggest single payer institution of Universal Health Coverage program in the world (Teh, 2015). The target is to reach 100\% coverage in 2019 (Presiden Republik Indonesia, 2004). The rapid expansion of insurance coverage has created a demand which cannot be met by the current healthcare system (Bredenkamp et al., 2015). Furthermore, Bredenkamp et al. (2015) state that the sudden increase of demand will disrupt the delivery of service, especially in the public hospitals. The disruption of service, consequently, will influence the satisfaction level. The Center for Health Economic and Policies Study from the University of Indonesia showed that the satisfaction level of hospital service is $54 \%$. The satisfaction level of doctor service is $44 \%$ (Thabrany, 2016). In one of descriptive study done by Dwidienawati \& Abdinagoro (2017), reasons like long queues, long waiting times, poor service, discrimination in procedure, and treatment procedures are the most common patient complaints. The results of the study seem confirm Oliver (2015)'s statement that fairness is another principal factor influencing satisfaction, besides quality.

This study is a pilot study aiming to see the impact of three variables of service fairness on customer satisfaction and how it will impact intention to pay or continuance of insurance premium payment.

\section{Literature Review \\ Service Fairness}

The terminology "justice" and "fairness" have been used interchangeably in many studies. There is no specific reason why some authors use "justice" and others use "fairness". Considering that this study deals more with the principle of equality rather than liberty, the terminology "fairness" is chosen instead of "justice" in this writing. Su \& Hsu (2013b) state that in justice theory, a customer evaluates a service encounter as either just or unjust. Service quality and service fairness are distinctive concepts. It is said that individuals are motivated by comparison to others. Carr (2007) states that no matter how good the service, one will be more satisfied if he or she gets the same level of services as other customers. Service fairness is a customer's perception of the degree of justice in a service firm's behaviour (Su \& Hsu, 2013b).

Researchers have found that besides quality evaluation, fairness is another important factor which influences satisfaction (Oliver, 2015). Oliver and Swan (1988), in Vinagre \& Neves (2010), confirm that as disconfirmation of expectation, fairness has been considered an important predictor of satisfaction. In general, it is assumed that patients are satisfied when they perceive treatment as fair (Oliver, 2015).

There are three variables of service fairness. The first one is distributive fairness (DF). DF is concerned with how the outcomes are distributed equitably (Kandul, 2016). The second variable of service fairness is procedural fairness (PF). PF refers to the process and procedures by which allocation decisions are made (Folger and Greenberg, 1985; Thibault and Walker, 1975), as stated in J. B. DeConinck (2010b). PF reflects a transparency system that signals that all customers will be treated fairly (Kashyap \& Sivadas, 2012). The last variable is interactional fairness (IF). IF is the way the customer is treated in terms of respect, politeness, and appreciation of other thoughts (Kashyap \& Sivadas, 2012). IF refers to the interpersonal treatment within the organisation (Bies and Moag, 1986), as stated in J. B. DeConinck (2010b) . It focuses on the fairness of interactional communication and procedures (Karkoulian et al., 2016). IF is a perceived fairness of treatment (Yilmaz et al., 2016c). It includes interpersonal, such as courtesies and politeness, and informational, such as delivering all the related information well (Jung, Brown, \& Zablah, 2017).

$\mathrm{DF}, \mathrm{PF}$, and IF all have significant contributions to satisfaction. Some studies considered IF, PF, and DF as individual variables having a direct influence on satisfaction (Chebat \& Slusarczyk, 2005; Kashyap \& Sivadas, 2012; Poujol, Siadou-martin, Vidal, \& Pellat, 2013; Sparks \& Mccoll-kennedy, 2001a; Vinagre \& Neves, 2010). Other studies considered IF, PF, and DF as dimensions of overall fairness (Carr, 2007; Su \& Hsu, 2013a; Zhu \& Chen, 2012). Beugre \& Baron (2001) call the overall fairness, which consists 
of IF, DF, and PF, as systemic fairness in the study in organisational fairness. Su \& Hsu (2013a), in their study on the tourism industry, call the overall fairness service fairness. This study will consider IF, PF, and DF as variables of service fairness. This study reviews individual variables of service fairness, because the impact of each variable on satisfaction might not be similar.

\section{Satisfaction}

Oliver (2015) defines satisfaction as "the consumer's fulfilment response", a post consumption judgment by the consumer that a service provides a pleasing level of consumption-related fulfilment, including under- or over-fulfilment. Satisfaction is a consumer positive affective response to a relationship exchange (Kashyap \& Sivadas, 2012). Consumer satisfaction is at the very core of marketing theory and practice (Newsome \& Wright, 1999). Since retaining customers may be more profitable than attracting new ones, dissatisfied customers may lead to unfavourable behaviour intentions, such as negative word of mouth, doing less business, or switching to an alternative service provider (Ramsaran-Fowdar, 2008).

Patients' satisfaction is an important indicator to evaluate the achievement of the public service system (Roberts \& Reich, 2002). Investigating public satisfaction is the most common way to confirm public opinion and needs for policy innovation. Greater involvement of consumers is needed in the health care process, partly because of the link demonstrated to exist between satisfaction and patient compliance in areas like appointment keeping, intentions to comply with recommended treatments, and medication use. Since high quality clinical outcome depends on compliance, which indirectly depends on patients' satisfaction, the latter has become a legitimate healthcare goal and, therefore, a prerequisite of quality care (Newsome \& Wright, 1999). Patients' satisfaction is also important to improve treatment outcomes (Gill \& White, 2013). Patients' satisfaction affects healthcare providers financially through referrals and reimbursement. Patients' satisfaction has also been linked to unsolicited complaints and medical malpractice lawsuits (Stelfox, Gandhi, Orav, \& Gustafson, 2005).

\section{Intention}

Retaining customers may be more profitable than attracting them. Clancy and Schulman (1994), in Ramsaran-Fowdar (2008), calculated that the cost of attracting new customers is approximately five times that of keeping current customers happy. Customer loyalty is an important goal in the consumer marketing community, as it is a key component for long-term viability and sustainability (Su \& Hsu, 2013). Customer loyalty refers to "the customers' willingness to continue patronising a business over the long-term, purchasing and using its goods and services on a repeated and preferably exclusive basis, and voluntarily recommending the firm's products to friends and associates" (Lovelock \& Wirtz, 2011). Zeithaml, Berry, \& Parasuraman (1996) suggested that one favourable behavioural intention is associated with a service provider's ability to get customers to spend more money with them. Loyalty is a construct comprising several dimensions. Repurchase intention and re-patronising intention represent the most common variables in existing empirical studies (Söderlund \& Colliander, 2015). Customer intention is the willingness of the customer to perform specific behaviour (Amoroso \& Lim, 2017).

\section{Hypothesis}

Previous studies show that satisfaction is the common outcome of fairness (Fernandes \& Calamote, 2016; Poujol et al., 2013; Ramsaran-Fowdar, 2008; Söderlund \& Colliander, 2015). The relationship of fairness to intention mostly is mediated by satisfaction (Fernandes \& Calamote, 2016; Poujol et al., 2013; Ramsaran-Fowdar, 2008; Söderlund \& Colliander, 2015; Su \& Hsu, 2013a). IF is sensitive to the amount of personal interaction in the transaction (Oliver, 2015). In the service or organisational process where personal interaction is key, there is a strong influence of interactional fairness on satisfaction. In retail banking, Chebat and Slusarczyk (2005) show the influence of interactional fairness and distributive fairness on satisfaction in service recovery is stronger than procedural fairness. They even show a direct influence of interactional fairness to loyalty. In healthcare, Neves (2010) show the strong influence of interactional fairness on satisfaction. The evidences of the strong influence of IF are supported by the studies from Jung et al. (2017), Deconinck \& Bachmann (2005), Kashyap \& Sivadas (2012), Mattila et al. (2011), Bradley \& Sparks (2012), Hui \& Au (2001), and Karkoulian et al. (2016).

Health care service involves strong personal interaction; therefore, a strong influence of interactional fairness on satisfaction is expected. 


\section{H1: Interactional Fairness positively influences Customer Satisfaction}

Procedural Fairness (PF) will become important in a situation where people judge the process on delivered outcome. In organisational behaviour studies, for service recovery and business relationships, PF is an important variable to outcomes. In an organisation behaviour study on performance appraisal by Karkoulian et al. (2016), a study on quota setting by Brashear et al. (2004), and a study on franchisefranchisee relationships (Kashyap \& Sivadas, 2012), all concur that having a perceived transparent process increases satisfaction, trust, and commitment. Service recovery and price fairness studies (Bechwati, Sisodia, \& Sheth, 2009; J. DeConinck \& Bachmann, 2005; Goudarzi et al., 2013; Gustafsson, 2009; Homburg et al., 2014; Malc et al., 2016; Ro \& Olson, 2014; Sharifi \& Aghazadeh, 2016; Yilmaz, Varnali, \& Tari, 2016b; Yilmaz et al., 2016c) show that quick responses, simple processes, and no-hassle processes increase outcomes. Complicated procedures are one of the most complained about item by BPJS Kesehatan Patients. It is therefore assumed that PF will have an influence on satisfaction delivery.

\section{H2: Procedural Fairness positively influences Customer Satisfaction}

The review of studies on fairness reveals that studies which show a strong influence of Distributive Fairness (DF) to outcomes are studies where customers or employees compare what they gain with what they have contributed. Employees are willing to help others (give extra miles) if employees perceived fair reward relocation (Chan \& Lai, 2017). In the emotionally exhausted working environment, perceived fairness in reward relocation strongly influences employee loyalty (J. C. Hur \& Jang, 2016). When customers feel the 'loss' (service is not as good as they expected), tangible compensation (DF) is important for post-complaint satisfaction (Hui \& Au, 2001; Noone, 2012; Sparks \& Mccoll-kennedy, 2001b; Yilmaz et al., 2016c). Not all BPJS Kesehatan members are using the services; in other words, some are contributing but never use the service or only use the service a few times. In this case, DF will be one of the factors influencing satisfaction.

\section{H3: Distributive Fairness positively influences Customer Satisfaction}

Customers develop attitudes towards products or services if they have consumed or experienced those products or services. Previous consumption and experiences will develop the like or dislike of the products and services. Therefore, satisfaction plays significant role in the behaviour post-consumption, such as repurchase intention (Oliver, 2015). The intimate relationship connecting satisfaction to loyalty is widely acknowledged in the marketing literature. Studies show that satisfied customers are more likely to be loyal than dissatisfied ones (Fornell, 1992; Fornell and Wernefelt, 1987; Parasuraman et al., 1991; Reichheld and Sasser, 1990), in (Poujol et al., 2013). Indeed, satisfaction has proven to be a major antecedent to loyalty (Bitner, 1990; Dick and Basu, 1994; Fornell et al., 1996), in (Poujol et al., 2013). Satisfaction has been suggested as direct antecedent of behavioural intentions in studies from various industries (Cho, Rutherford, \& Park, 2013; Gao \& Mattila, 2014; Hosany \& Prayag, 2013; Su \& Hsu, 2013a), or mediated by trust (Han \& Sean, 2015).

The relationship between customer satisfaction and intention is proposed as:

\section{H4: Customer Satisfaction positively influences Intention to Pay the BPJS insurance premium}

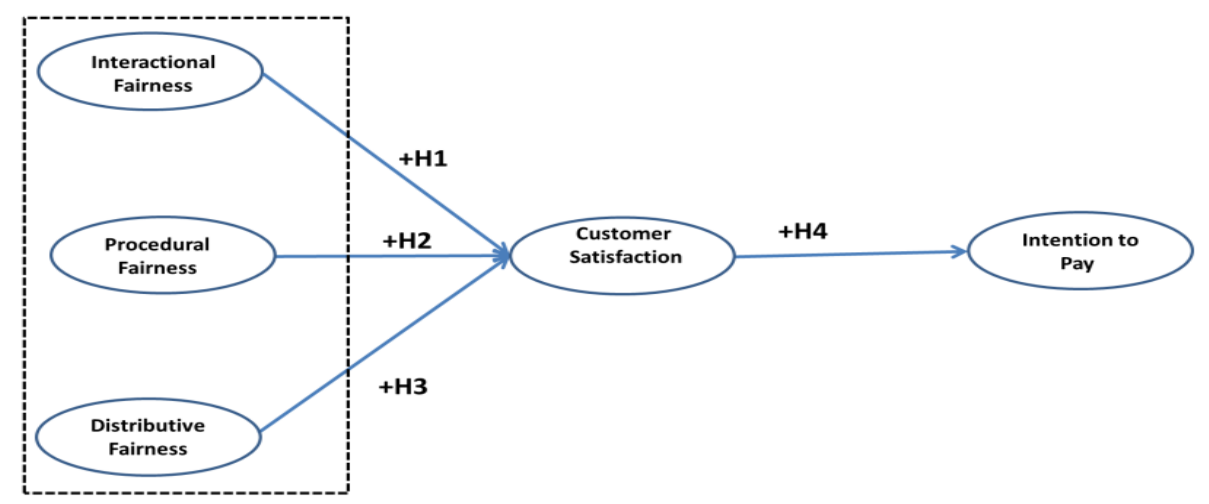

Figure 1. Research Framework (Dwidienawati \& Pradipto, 2017) 


\section{Method}

The study is a descriptive quantitative study. Research unit analysis is the individual member of BPJS Kesehatan Mandiri (a member who contributes by paying an insurance premium on a monthly base). Therefore, the population of this study is all BPJS Kesehatan Mandiri members, which total approximately 61 million. Data for statistical analysis were gathered through an online survey of BPJS Kesehatan Mandiri members in November 2017.

The survey was administered in five big cities on Java Island, Indonesia. The survey was designed to elicit items for the constructs in the model and focused on service fairness judgement (IF, PF, and DF) of BPJS Kesehatan providers (medical professionals and hospital staff), customer satisfaction, and intention to pay the insurance premium of BPJS Kesehatan. This is a pilot study; therefore, only a total of 58 questionnaires were used to test the model. Sample collection used the convenience sample collection method, due to time and resource limitations.

\section{Measures}

The survey explored respondents' judgments of the service fairness, customer satisfaction, and intention to pay the insurance premium. In the survey, respondents were asked to rate their level of agreement with items using a 6-point Likert scale anchored with strongly disagree and strongly agree. Mid-point is omitted to avoid social desirability bias.

IF was measured using four indicators modified from Carr (2007) and Shafiri \& Aghazadeh (2016), taping the respondent evaluation on service providers' politeness, courtesy, and empathy. PF was measured using three indicators modified from Carr (2007), Poujol (2013), and Vinagre \& Neves (2010), taping the respondent evaluation on process and procedure delivered by service providers. DF was measured using three indicators modified from Poujol (2013) and Vinagre \& Neves (2010), taping respondent judgment on whether input/output of the process relative to other customers is fair. Satisfaction was measured using three indicators modified from Carr (2007) and Kasyap \&Sivadas (2012), taping the respondent evaluation on satisfaction of interaction, support, and service. Intention to pay was measured using three indicators modified from Su and Hsu (2013) and Carr (2007), taping the respondent evaluation on intention of continuance of payment, paying more, and helping the program.

\section{Measurement model}

Due to the small number of samples, PLS-SEM was used with SMART-PLS software. PLS-SEM was chosen because of its advantages over covariance-based modelling, and because it produces robust results for small sample sizes (Hair, Hult, Ringle, \& Sarstedt, 2017). The model was evaluated for measurement and structural evaluation and, finally, hypotheses testing. From 58 questionnaires distributed, 30 questionnaires were returned $(51 \%)$ and eligible to be analysed. Statistical analysis confirms that the measurement model is reliable and valid (Table 1). There is one indicator with a convergent less than 0.7. According to Hulland (1999), in Hair et al. (2017), the convergent validity for social science can be less than 0.7 .

If the convergent validity is between $0.4-0.7$, the indicator is deleted, and composite reliability increases, the indicator should be retained. The composite reliability increased when that indicator was deleted; therefore, the indicator was retained. Based on the results of statistical analysis of the measurement model, it is concluded that the indicators are fit to the assigned construct. 
Table 1. Summary of Measurement Model

\begin{tabular}{|c|c|c|c|c|c|c|c|}
\hline $\begin{array}{c}\text { Latent } \\
\text { Variable }\end{array}$ & Indicator & $\begin{array}{c}\text { Covergent } \\
\text { Validity }\end{array}$ & & & $\begin{array}{c}\text { Internal } \\
\text { Consistency } \\
\text { Reliability }\end{array}$ & & $\begin{array}{l}\text { Discriminant } \\
\text { Validity }\end{array}$ \\
\hline & & Loading & $\begin{array}{c}\text { Indicator } \\
\text { Reliability }\end{array}$ & AVE & $\begin{array}{l}\text { Composite } \\
\text { Reliability }\end{array}$ & $\begin{array}{c}\text { Cronbach's } \\
\text { Alpha }\end{array}$ & \\
\hline & & $>0.7$ & $>0.5$ & $>0.5$ & $0.6-0.9$ & $0.6-0.9$ & $\begin{array}{c}\text { HTMT } \\
\text { Convidence } \\
\text { Interval does not } \\
\text { include } 1\end{array}$ \\
\hline \multirow{4}{*}{ INF } & INF01 & 0.893 & \multirow{4}{*}{0.939} & \multirow{4}{*}{0.838} & \multirow{4}{*}{ YES } & \multirow{4}{*}{ YES } & \multirow{4}{*}{ YES } \\
\hline & INF02 & 0.908 & & & & & \\
\hline & INF03 & 0.874 & & & & & \\
\hline & INF04 & 0.929 & & & & & \\
\hline \multirow{3}{*}{ PCF } & PCF01 & 0.792 & \multirow{3}{*}{0.823} & \multirow{3}{*}{0.620} & \multirow{3}{*}{ YES } & \multirow{3}{*}{ YES } & \multirow{3}{*}{ YES } \\
\hline & PCF02 & 0.838 & & & & & \\
\hline & PCF03 & 0.735 & & & & & \\
\hline \multirow{3}{*}{ DTF } & DTF01 & 0.518 & \multirow{3}{*}{0.829} & \multirow{3}{*}{0.619} & \multirow{3}{*}{ YES } & \multirow{3}{*}{ YES } & \multirow{3}{*}{ YES } \\
\hline & DTF02 & 0.889 & & & & & \\
\hline & DTF03 & 0.897 & & & & & \\
\hline \multirow{3}{*}{ SAT } & SAT01 & 0.821 & \multirow{3}{*}{0.945} & \multirow{3}{*}{0.812} & \multirow{3}{*}{ YES } & \multirow{3}{*}{ YES } & \multirow{3}{*}{ YES } \\
\hline & SAT02 & 0.958 & & & & & \\
\hline & SAT03 & 0.96 & & & & & \\
\hline \multirow{3}{*}{ INT } & INT01 & 0.844 & \multirow{3}{*}{0.831} & \multirow{3}{*}{0.622} & \multirow{3}{*}{ YES } & \multirow{3}{*}{ YES } & \multirow{3}{*}{ YES } \\
\hline & INT02 & 0.746 & & & & & \\
\hline & INT03 & 0.767 & & & & & \\
\hline
\end{tabular}

\section{Results}

From total 58 questionnaires distributed, 51 questionnaires were returned (88\%). After assessing the completeness of questionnaires and deleting the duplications, 30 questionnaires (52\%) were eligible for statistical analysis. Demographics of the respondents can be seen in Table 2. Most of the respondents have been BPJS member since 2014/2015, or the first and second years of the BPJS Kesehatan launch. Most of them have encountered BPJS Kesehatan providers in private hospitals.

Table 2. Respondent Demographics

\begin{tabular}{|c|c|c|}
\hline \multirow[t]{3}{*}{ Age } & $25-35$ & $33 \%$ \\
\hline & $35-45$ & $33 \%$ \\
\hline & $45-55$ & $33 \%$ \\
\hline \multirow[t]{3}{*}{ Education Background } & High School & $10 \%$ \\
\hline & Bachelor & $80 \%$ \\
\hline & Master & $10 \%$ \\
\hline \multirow[t]{3}{*}{ Member BPJS Since } & $2014 / 2015$ & $80 \%$ \\
\hline & 2016 & $13 \%$ \\
\hline & 2017 & $7 \%$ \\
\hline Encounter with BPJS & Private & \\
\hline \multirow[t]{4}{*}{ Kesehatan Provider } & Hospital & $43 \%$ \\
\hline & Public & \\
\hline & Hospital & $23 \%$ \\
\hline & Both & $23 \%$ \\
\hline
\end{tabular}

Statistical analysis for evaluating the structural model showed that the $\mathrm{R}^{2}$ of IF, PF, and DF to Customer Satisfaction is 0.658, where the $\mathrm{R}^{2}$ Customer Satisfaction to Intention to Pay is 0.361. Hair (2011) and Henseler et al. (2009), in Hair et al. (2017), stated that within the scholarly research on marketing issues, $R^{2}$ values of $0.75,0.5$, or 0.25 for endogenous variables can be described as substantial, moderate, or 
weak. Therefore, based on $\mathrm{R}^{2}$, the endogenous variables in the model can explain moderately their exogenous variables. In addition to evaluating $\mathrm{R}^{2}, \mathrm{f}^{2}$ was also evaluated and the results are shown in Table 3.

\begin{tabular}{lll}
\multicolumn{3}{c}{ Table 3. $\mathrm{f}^{2}$ Measurement Results } \\
\hline & $\begin{array}{l}\text { Customer } \\
\text { Satisfaction Pay }\end{array}$ \\
\hline Customer Satisfaction & & 0.564 \\
\hline Distributive Fairness & 0.376 & \\
\hline Intention to Pay & & \\
\hline Interactional Fairness & 0.295 & \\
\hline Procedural Fairness & 0.005 & \\
\hline
\end{tabular}

Referring to Cohen (1998) and Hair et al. (2017), only the $\mathrm{f}^{2}$ from PF to Customer Satisfaction is considered small $(<0.02)$. Looking at the path coefficient value, the path coefficient from PF to Customer Satisfaction is very low, at 0.0049 . The size effect of DF and IF is large and medium.

Table 4. Path Coefficient

\begin{tabular}{lccccc}
\hline & $\begin{array}{c}\text { Original } \\
\text { Sample (O) }\end{array}$ & $\begin{array}{c}\text { Sample Mean } \\
(\mathbf{M})\end{array}$ & $\begin{array}{c}\text { Standard } \\
\text { Deviation } \\
\text { (STDEV) }\end{array}$ & $\begin{array}{c}\text { T Statistics } \\
(\mid \mathbf{O} / \text { STDEV|) }\end{array}$ & P Values \\
\hline $\begin{array}{l}\text { Customer Satisfaction -> } \\
\text { Intention to Pay }\end{array}$ & 0.601 & 0.641 & 0.079 & 7.647 & 0.000 \\
\hline $\begin{array}{l}\text { Distributive Fairness -> } \\
\text { Customer Satisfaction }\end{array}$ & 0.447 & 0.458 & 0.128 & 3.494 & 0.001 \\
\hline $\begin{array}{l}\text { Interactional Fairness -> } \\
\text { Customer Satisfaction }\end{array}$ & 0.433 & 0.411 & 0.157 & 2.767 & 0.006 \\
\hline $\begin{array}{l}\text { Procedural Fairness -> } \\
\text { Customer Satisfaction }\end{array}$ & 0.049 & 0.062 & 0.142 & 0.344 & 0.731 \\
\hline
\end{tabular}

Table 4 shows that PF is not significant in influencing Customer Satisfaction ( $\mathrm{P}$ Value $=0.731)$. The other two variables, DF and PF, are significant in influencing Customer Satisfaction. Customer Satisfaction is confirmed to have a positive relationship with Intention to Pay. Thus, hypotheses 1, 3, and 4 are accepted, while hypothesis 2 is rejected.

\section{Discussion}

Patients' satisfaction is the principal factor in evaluating a public service program. Moreover, patients' satisfaction also plays a role in improving patient's treatment outcome (Gill \& White, 2013; Roberts \& Reich, 2002). Different treatments and complicated procedures are the most common complaints about BPJS Kesehatan. Therefore, understanding whether DF, PF, and IF judgments influence satisfaction in BPJS Kesehatan service delivery is important.

Assorted studies show that the magnitude of influence of individual variables of Service Fairness to Satisfaction is not similar. The impact is different from one study to another. Ro \& Olson (2014), Kashyap \& Sivadas (2012), and Sparks \& Mccoll-kennedy (2001) argue that all three variables of fairness are equally important in influencing satisfaction. DF was found dominant in the studies from Yilmaz, Varnali, \& Tari (2016), Chan \& Lai (2017), and Hui \& Au (2001). Yilmaz et al. (2016), Shahin \& Aghazadeh (2016), Homburg et al., (2014), Gustafsson (2009), and Karkoulian, Assaker, \& Hallak (2016) argue that PF has a strong influence on satisfaction, loyalty, and trust. IF is reported to have a dominant influence by Deconinck \& Bachmann (2005), Bradley \& Sparks (2012), and Karkoulian et al. (2016).

Healthcare service is a credence business. Patients have no ability to assess the service's technical reliability. Donabedian (1997) states that since patients, most of the time, are in no position to assess the technical quality of the care process, they are sensitive to interpersonal relationships. Studies on the SERVQUAL influence on satisfaction in healthcare show that the most important variable of service influencing satisfaction are ones which involve interpersonal elements. These are empathy and 
attentiveness. Those two variables involve staff communication, physician behaviour, staff demeanour, and interpersonal skills (Boquiren et al, 2015; Devija et al., 2012; Park et al., 2016; Saeed et al., 2013). Similarly, with the service fairness variable in the health care industry, IF will play a significant role in influencing Customer Satisfaction.

IF is sensitive to the amount of personal interaction within the transaction (Oliver, 2015). In the service or organisational process where personal interaction is key, there is a strong influence of interactional fairness to satisfaction. In retail banking, Chebat and Slusarczyk (2005) show the influence of interactional fairness and distributive fairness to satisfaction in service recovery is stronger than procedural fairness. Karkoulian et al. (2016) show that in performance appraisal, how the supervisor treats subordinates will influence employees' satisfaction. Hui \& Au (2001) show that culture influences which variable of fairness is important in-service recovery. Service delivery in healthcare involves many interpersonal interactions. Furthermore, patients usually require more empathy and care; therefore, they are quite sensitive to how service providers treat them. This study confirms the previous studies on SERQUAL and Service Fairness, that when interpersonal interaction is involved, variables related to interactional, in this case IF, will have a strong influence on satisfaction (Boquiren et al., 2015; Devija et al., 2012; Park et al., 2016; Saeed et al., 2013; Neves, 2010)

In a society where social behaviour is still collectivist, values respect, status, and face (Asian culture in general), personal interaction and politeness are important factors for increasing the satisfaction level. Mattila et al. (2011) argue that in online service recovery, tangible compensation and apology via email is not enough. Human connection may be needed to ensure satisfaction. Indonesia, just like any other Asian country, has a collectivist, saving face, and value respect type of culture. Therefore, how medical professionals and hospital staff treat patients fairly will influence their judgement of satisfaction.

This study also confirms that DF influences Customer Satisfaction. Previous studies revealed that a strong influence of DF on Satisfaction occurs when customers or employees compare what they gain with what they have contributed (Hui \& Au, 2001; Noone, 2012; Sparks \& Mccoll-kennedy, 2001b; Yilmaz et al., 2016a). A study from Chan and Lai (2017) shows that when employees perceive being rewarded fairly, they will feel satisfied, and even go extra miles. BPJS Kesehatan members might consider that their contribution is comparable with what they get. So even though they contribute by paying a premium every month, the value might be too insignificant compared to the perceived return; therefore, they consider the input and outcome distribution are fair and satisfying.

PF will become important in a situation when people judge the process on the delivered outcome. Having a perceived transparent process will increase satisfaction, trust, and commitment (Kashyap \& Sivadas, 2012). In this study, even though the respondents admit that there are different processes and procedures, only some of the respondents comment that they understand why the process is different with regular patients. They do understand that for an insurance patient, the process and procedure is different compared to regular patients. Therefore, they don't consider different processes and procedures unfair. This study further confirms the intimate relationship connecting satisfaction to intention, as reported by Fornell (1992), Fornell and Wernefelt (1987), Parasuraman et al. (1991), and Reichheld and Sasser (1990), in Poujol et al. (2013). This study strengthens satisfaction as a major antecedent to loyalty (Bitner, 1990; Dick and Basu, 1994; Fornell et al., 1996), in Poujol et al. (2013).

\section{Conclusion}

This study strengthened the empirical evidences of the impact of IF and DF on customer satisfaction. Considering the high interaction between patients, medical professionals, and hospital staff, IF showed a positive impact on customer satisfaction. DF influences customer satisfaction positively also, since BPJS Kesehatan members considered what they gained was relatively fair or better than what they had contributed. However, this study failed to prove the relationship between PF and customer satisfaction. Patients understood that BPJS Kesehatan processes and procedures were different for them compared to regular patients. Therefore, they did not consider different process and procedure as unfair.

This study also further confirmed the intimate relationship connecting satisfaction to intention. This study strengthened satisfaction as a major antecedent to loyalty. The limitation of this study is that this study is a pilot study with a small sample size. Further studies with larger sample sizes, with a mix 
method design, should be conducted to have a generalisation and gain more understanding on the reasons why patients do not mind having different procedures, but do mind having different treatment.

This study contributes to the body of evidence on the relationship or service fairness to satisfaction and, indirectly, to intention to pay, specifically in the service delivery within the healthcare industry.

\section{References}

Abubakar, A. M., Ilkan, M., Meshall Al-Tal, R., \& Eluwole, K. K. (2017). eWOM, revisit intention, destination trust and gender. Journal of Hospitality and Tourism Management, 31, 220-227. https://doi.org/10.1016/j.jhtm.2016.12.005

Amoroso, D., \& Lim, R. (2017). The mediating effects of habit on continuance intention. International Journal of Information Management, 37(6), 693-702. https:// doi.org/10.1016/j.ijinfomgt.2017.05.003

Bechwati, N. N., Sisodia, R. S., \& Sheth, J. N. (2009). Developing a model of antecedents to consumers' perceptions and evaluations of price unfairness. Journal of Business Research, 62, 761-767.

https://doi.org/10.1016/j.jbusres.2008.09.004

Beugre, D., \& Baron, A. (2001). Perceptions of Systemic Justice: The Effects of Distributive, Procedural, and Interactional Justice. Journal of Applied Psychology, 31(2), 324-339.

Boquiren, V. M., Hack, T. F., Beaver, K., \& Williamson, S. (2015). Patient Education and Counseling What do measures of patient satisfaction with the doctor tell us? Patient Education and Counseling, 98(12), 1465-1473. https://doi.org/10.1016/j.pec.2015.05.020

Bradley, G., \& Sparks, B. (2012). Explanations: if, when, and how they aid service recovery. Journal of Services Marketing, 26(1), 41-51. https://doi.org/10.1108/08876041211199715

Brashear, T. G., Brooks, C. M., \& Boles, J. S. (2004). Distributive and procedural justice in a sales force context Scale development and validation. Journal of Business Research, 57, 86-93. https://doi.org/10.1016/S01482963(02)00288-6

Bredenkamp, C., Evans, T., Lagrada, L., Langenbrunner, J., Nachuk, S., \& Palu, T. (2015). Emerging challenges in implementing universal health coverage in Asia. Social Science \& Medicine, 145, 243-248.

https://doi.org/10.1016/j.socscimed.2015.07.025

Brown, J. R., Cobb, A. T., \& Lusch, R. F. (2006). The roles played by interorganizational contracts and justice in marketing channel relationships. Journal of Business Research, 59, 166-175.

https://doi.org/10.1016/j.jbusres.2005.04.004

Carr, C. L. (2007). The FAIRSERV Model: Consumer Reactions to Services Based on a Multidimensional Evaluation of Service Fairness. Decision Science, 38(1), 107-130.

Chan, S. H. J., \& Lai, H. Y. I. (2017). Understanding the link between communication, satisfaction, perceived justice, and organizational citizenship behaviour. Journal of Business Research, 70, 214-223.

https://doi.org/10.1016/j.jbusres.2016.08.017

Chebat, J., \& Slusarczyk, W. (2005). How emotions mediate the effects of perceived justice on loyalty in service recovery situations: an empirical study. Journal of Business Research, 58, 664-673.

https://doi.org/10.1016/j.jbusres.2003.09.005

Cho, Y., Rutherford, B. N., \& Park, J. (2013). The impact of emotional labor in a retail environment. Journal of Business Research, 66, 670-677. https://doi.org/10.1016/j.jbusres.2012.04.001

DeConinck, J. B. (2010a). The effect of organizational justice perceived organizational support, and perceived supervisor support on marketing employees' level of trust. Journal of Business Research, 63, 1349-1355. https:// doi.org/10.1016/j.jbusres.2010.01.003

DeConinck, J. B. (2010b). The influence of ethical climate on marketing employees' job attitudes and behaviors. Journal of Business Research, 63, 384-391b. https://doi.org/10.1016/j.jbusres.2008.11.009

DeConinck, J., \& Bachmann, D. (2005). An analysis of turnover among retail buyers. Journal of Business Research, 58, 874-882. https://doi.org/10.1016/j.jbusres.2003.10.009

Devija, P., Bhandari, S., \& Agal, S. (2012). Factors Influencing the Patients in Attaining Satisfaction by the Services Provided in the Hospital. International Journal of Management \& Business Studies, 2(3), 95-98.

Dwidienawati, D., \& Abdinagoro, S. B. (2017). Does Generosity Influence Intention to Continue Paying Insurance Premium? Case of Indonesia's BPJS Kesehatan. In 4th Global Conference on Business and Social Sciences (p. 117).

Dwidienawati, D., \& Pradipto, Y. D. (2017). Influence of Fairness to BPJS Kesehatan Patients' Satisfaction: Conceptual Model from Critical Review. In Conference in Interdisciplinary Business and Economics Research (pp. 1-16).

Fernandes, T., \& Calamote, A. (2016). Unfairness in consumer services: Outcomes of differential treatment of new and existing clients. Journal of Retailing and Consumer Services, 28, 36-44

. https://doi.org/10.1016/j.jretconser.2015.08.008

Fernet, C., Trépanier, S. G., Demers, M., \& Austin, S. (2017). Motivational pathways of occupational and organizational turnover intention among newly registered nurses in Canada. Nursing Outlook, 65(4), 444-454. https://doi.org/10.1016/j.outlook.2017.05.008 
Gan, C., \& Li, H. (2018). Understanding the effects of gratifications on the continuance intention to use WeChat in China: A perspective on uses and gratifications. Computers in Human Behavior, 78, 306-315. https://doi.org/10.1016/j.chb.2017.10.003

Gao, Y., \& Mattila, A. S. (2014). Improving consumer satisfaction in green hotels: The roles of perceived warmth, perceived competence, and CSR motive. International Journal of Hospitality Management, 42, 20-31.

https:// doi.org/10.1016/j.ijhm.2014.06.003

Gill, L., \& White, L. (2013). A critical review of patient satisfaction. Leadership in Health Services, 22(1), 8-19.

https://doi.org/10.1108/17511870910927994

Gill, L., White, L., Gill, L., \& White, L. (2013). A Critical Review of Patient Satisfaction. Leadership in Health Services, 22(1), 8-19. https://doi.org/10.1108/17511870910927994

Goodwin, C., \& Ross, I. (1992). Consumer Responses to Service Failures: Influence of Procedural and Interactional Fairness Perceptions. Journal Business Research, 163, 149-163.

Goudarzi, K., Borges, A., \& Charles, J. (2013). Should retailers pay to bring customers back? The impact of quick response and coupons on purchase outcomes. Journal Business Research, 66, 665-669.

https://doi.org/10.1016/j.jbusres.2012.02.042

Gustafsson, A. (2009). Customer satisfaction with service recovery. Journal of Business Research, 62, $1220-1222$. https://doi.org/10.1016/j.jbusres.2008.11.001

Han, H., \& Sean, S. (2015). Customer retention in the medical tourism industry: Impact of quality, satisfaction, trust, and price reasonableness. Tourism Management, 46, 20-29. https://doi.org/10.1016/j.tourman.2014.06.003

Homburg, C., Totzek, D., \& Krämer, M. (2014). How price complexity takes its toll: The neglected role of a simplicity bias and fairness in price evaluations. Journal of Business Research, 67, $1114-1122$. https://doi.org/10.1016/j.jbusres.2013.05.049

Hosany, S., \& Prayag, G. (2013). Patterns of tourists â€TM emotional responses, satisfaction, and intention to recommend. Journal of Business Research, 66, 730-737. https:/ / doi.org/10.1016/j.jbusres.2011.09.011

Hui, M. K., \& Au, K. (2001). Justice perceptions of complaint-handling A cross-cultural comparison between PRC and Canadian customers. Journal of Business Research, 52, 161-173.

Hur, J. C., \& Jang, S. S. (2016). Toward service recovery strategies: the role of consumer-organization relationship norms. Journal of Services Marketing, 30(7), 724-736. https:/ / doi.org/10.1108/JSM-08-2015-0263

Hur, W. M., Park, S. Il, \& Moon, T. W. (2014). The moderating roles of organizational justice on the relationship between emotional exhaustion and organizational loyalty in airline services. Journal of Services Marketing, 28(3), 195-206. https://doi.org/10.1108/JSM-07-2012-0118

Hussein, Z., Oon, S. W., \& Fikry, A. (2017). Consumer Attitude: Does It Influencing the Intention to Use mHealth? Procedia Computer Science, 105(December 2016), 340-344. https://doi.org/10.1016/j.procs.2017.01.231

Joo, Y. J., Park, S., \& Shin, E. K. (2017). Students' expectation, satisfaction, and continuance intention to use digital textbooks. Computers in Human Behavior, 69, 83-90. https://doi.org/10.1016/j.chb.2016.12.025

Jung, J. H., Brown, T. J., \& Zablah, A. R. (2017). The effect of customer-initiated justice on customer-oriented behaviors. Journal of Business Research, 71, 38-46. https://doi.org/10.1016/j.jbusres.2016.10.019

Kandul, S. (2016). Ex-post blindness as excuse? The effect of information disclosure on giving. Journal of Economic Psycology, 52, 91-101. https:/ / doi.org/10.1016/j.joep.2015.11.006

Karkoulian, S., Assaker, G., \& Hallak, R. (2016). An empirical study of 360-degree feedback, organizational justice, and firm sustainability. Journal of Business Research, 69(5), 1862-1867. https:/ / doi.org/10.1016/j.jbusres.2015.10.070

Kashyap, V., \& Sivadas, E. (2012). An exploratory examination of shared values in channel relationships. Journal of Business Research, 65, 586-593. https://doi.org/10.1016/j.jbusres.2011.02.008

Liang, L. J., Choi, H. C., \& Joppe, M. (2018). Exploring the relationship between satisfaction, trust and switching intention, repurchase intention in the context of Airbnb. International Journal of Hospitality Management, 69(October 2017), 41-48. https://doi.org/10.1016/j.ijhm.2017.10.015

Malc, D., Mumel, D., \& Pisnik, A. (2016). Exploring price fairness perceptions and their influence on consumer behaviour. Journal of Business Research, 69(9), 3693-3697. https://doi.org/10.1016/j.jbusres.2016.03.031

Mattila, A. S., Cho, W., \& Cheyenne, H. (2011a). The role of self-service technologies in restoring justice. Journal Business Research, 64, 348-355. https://doi.org/10.1016/j.jbusres.2010.02.014

Mattila, A. S., Cho, W., \& Cheyenne, H. (2011b). The Role of Self-service Technologies in Restoring Justice. Journal of Business Research, 64, 348-355. https:// doi.org/10.1016/j.jbusres.2010.02.014

Mccoll-kennedy, J. R., Sparks, B. A., \& Nguyen, D. T. (2011). Customer' s angry voice: Targeting employees or the organization? Journal of Business Research, 64, 707-713. https://doi.org/10.1016/j.jbusres.2010.08.004

Newsome, P. R., \& Wright, G. H. (1999). A review of patient satisfaction: Concepts of satisfaction. British Dental Journal, 186(4), 161-165.

Noone, B. M. (2012). Overcompensating for severe service failure: perceived fairness and effect on negative word-ofmouth intent. Journal of Services Marketing, 26(5), 342-352. https://doi.org/10.1108/08876041211245254 
Oliver, R. L. (2015). Satisfaction A Behavioral Perspective on Consumer (2nd ed.). Oxon and New York: Routledge.

Park, K., Park, J., Dae Kwon, Y., Kang, Y., \& Noh, J.-W. (2016). Public satisfaction with the healthcare system performance in South Korea: Universal healthcare system. Health Policy, 120, 621-629.

https:/ / doi.org/10.1016/j.healthpol.2016.01.017

Poujol, J. F., Siadou-martin, B., Vidal, D., \& Pellat, G. (2013). The impact of salespeople's relational behaviors and organizational fairness on customer loyalty: An empirical study in B-to-B relationships. Journal of Retailing and Consumer Services, 20(5), 429-438. https://doi.org/10.1016/j.jretconser.2013.03.005

Prasongsukarn, K., Patterson, P. G., \& Patterson, P. G. (2012). An extended service recovery model: the moderating impact of temporal sequence of events. Journal of Services Marketing, 26(7), 510-520.

https://doi.org/10.1108/08876041211266477

Presiden Republik Indonesia. Undang-Undang No. 40 TH 2004 (2004).

Ramsaran-Fowdar, R. R. (2008). The relative importance of service dimensions in a healthcare setting. International Journal of Health Care Quality Assurance, 21(1), 104-124. https:/ / doi.org/10.1108/09526860810841192

Ro, H., \& Olson, E. D. (2014). The effects of social justice and stigma-consciousness on gay customers' service recovery evaluation. Journal of Business Research, 67(6), 1162-1169. https://doi.org/10.1016/j.jbusres.2013.05.006

Roberts, M. J., \& Reich, M. R. (2002). Getting Health Reform Right. Oxford University Press.

Saeed, R., Osama Ghafoor, M., Sarwar, B., Nawaz Lodhi, R., Muhammad Arshad, H., Ahmad, M., \& Professor, A. (2013). Factors Affecting Customer Satisfaction in Health Care Servicesin Pakistan. Journal of Basic and Applied Scientific Reserach, 3(5), 947-952.

Sekaran, U., \& Bougie, R. (2016). Reserach Methods fro Business (7th ed.). John Wiley \& Sons.

Sharifi, S. S., \& Aghazadeh, H. (2016). Discount reference moderates' customers' reactions to discount frames after online service failure. Journal of Business Research, 69, 4074-4080. https:// doi.org/10.1016/j.jbusres.2016.03.044

Söderlund, M., \& Colliander, J. (2015). Loyalty program rewards and their impact on perceived justice, customer satisfaction, and repatronize intentions. Journal of Retailing and Consumer Services, 25, 47-57. https:/ / doi.org/10.1016/j.jretconser.2015.03.005

Sparks, B. A., \& Mccoll-kennedy, J. R. (2001a). Justice strategy options for increased customer satisfaction in a services recovery setting. Journal of Business Research, 54, 209-218.

Sparks, B. A., \& Mccoll-kennedy, J. R. (2001b). Justice strategy options for increased customer satisfaction in a services recovery setting, 54, 209-218.

Stelfox, H. T., Gandhi, T. K., Orav, E. J., \& Gustafson, M. L. (2005). The relation of patient satisfaction with complaints against physicians and malpractice lawsuits. The American Journal of Medicine, 118, 1126-1133.

https://doi.org/10.1016/j.amjmed.2005.01.060

Su, L., \& Hsu, M. K. (2013a). Service Fairness, Consumption Emotions, Satisfaction, and Behavioral Intentions: The Experience of Chinese Heritage Tourists. Journal of Travel E Tourism Marketing, 30, 786-805.

https://doi.org/10.1080/10548408.2013.835228

Su, L., \& Hsu, M. K. (2013b). Service Fairness, Consumption Emotions, Satisfaction, and Behavioral Intentions: The Experience of Chinese Heritage Tourists. Journal of Travel E Tourism Marketing, (October 2014), 37-41.

https:// doi.org/10.1080/10548408.2013.835228

Teh, I. (2015). Universal healthcare coverage in Indonesia. The Economist.

Thabrany, H. (2016). Jaminan Kesehatan nasional. Raja Grafindo Persada (Vol. 3).

Vinagre, H., \& Neves, J. (2010). Emotional predictors of consumer's satisfaction with healthcare public services. International Journal of Health Care Quality Assurance, 23(2), 209-227.

https://doi.org/10.1108/09526861011017111

Yilmaz, C., Varnali, K., \& Tari, B. (2016a). How do firms benefit from customer complaints, 69, 944-955.

https://doi.org/10.1016/j.jbusres.2015.08.038

Yilmaz, C., Varnali, K., \& Tari, B. (2016b). How do firms benefit from customer complaints? Journal of Business Research, 69, 944-955. https://doi.org/10.1016/j.jbusres.2015.08.038

Yilmaz, C., Varnali, K., \& Tari, B. (2016c). How do firms benefit from customer complaints? Journal of Business Research, 69, 944-955. https://doi.org/10.1016/j.jbusres.2015.08.038

Zhu, Y., \& Chen, H. (2012). Service fairness and customer satisfaction in internet banking. Internet Research, 22(4), 482498. https://doi.org/10.1108/10662241211251006 